\title{
Apparent Faecal Digestibility of Essential Amino Acids from $\Omega 3$ Pufa Diets for Laying Hens
}

http://dx.doi.org/10.1590/1806-9061-2019-1025

EAuthor(s)

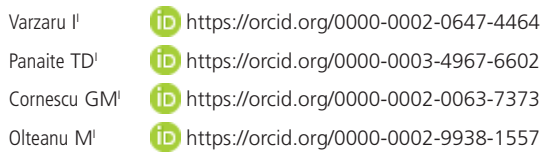

INCDBNA, National Institute of Research and Development for Biology and Animal Nutrition, Balotesti, Romania.

\section{-Mail Address}

Corresponding author e-mail address Iulia Varzaru

National Research Development Institute for Animal Biology and Nutrition, no 1, Calea Bucuresti, Balotesti, 077015, Ilfov Romania.

Phone: 0040213512081

Email: iulia_maros@yahoo.com

\section{aKeywords}

Amino acid digestibility, PUFA enriched diets, laying hen.

\section{ABSTRACT}

The apparent faecal digestibility of the essential amino acids from $\Omega 3$ PUFA layer diets and feeding solutions to avoid possible adverse effects of such diets were investigated in two experiments conducted on Lohmann Brown laying hens. Experiment 1 used 72 layers assigned to three groups (C1, E1-1, E2), while experiment 2 used 96 layers assigned to four groups (C2, E1-2, E3, E4). All experimental diets have been enriched in $\Omega 3$ PUFA by supplementing a conventional diet (C1, C2) with $5 \%$ flaxseed meal and $2 \%$ camelina meal. Diets E2 and E4 had an increased level of $\mathrm{Cu}(150 \mathrm{mg} / \mathrm{kg})$, diets E3 and E4 were supplemented with $0.0125 \%$ enzyme mix, while diets E1-1 and E1-2 were only supplemented with $5 \%$ flaxseed meal and $2 \%$ camelina meal. The digestibility coefficients of the studied essential amino acids (threonine, valine, phenylalanine, isoleucine, leucine, lysine, cystine, methionine) were lower $(p \leq 0.05)$ in groups E1-1 and E2 from experiment 1, than in the control group (C1). In experiment 2, the supplemental enzyme mix (E3) increased $(p \leq 0.05)$ the digestibility coefficients of phenylalanine, lysine, cystine and methionine, compared to the diet with camelina and flaxseed meals (E1-2). The simultaneous inclusion of copper and enzyme mix in the E4 diet increased $(p \leq 0.05)$ lysine digestibility compared to group E1-2 and sulphur amino acids digestibility, compared to the other groups (C2, E1-2 and E3). In both experiments, only the feed conversion ratio was different $(p \leq 0.05)$ in favour of the control groups (C1 and C2), compared to the other groups.

\section{INTRODUCTION}

A major interest to increase the concentration of $\Omega-3$ polyunsaturated fatty acids ( $\Omega-3$ PUFA) in human diets was noticed over the past two decades, following the research studies which proved their beneficial effects for human health (Liu \& Kim, 2018; Shahidi \& Ambigaipalan, 2018). Since the feeding value of the egg can be influenced by nutrition, $\Omega-3$ PUFA content from the hen's egg yolk can be increased in the same manner. Flaxseeds (Linum usitatissimum) and camelina (Camelina sativa) are among the oleaginous crops successfully used in layer diets to enrich the eggs in $\Omega-3$ PUFA (Cherian, 2017; Olteanu et al., 2016, Criste et al., 2009, Zotte et al., 2015), but the dietary level is limited by their antinutritional factors (Woyengo et al., 2017, Pekel et al., 2015).

The Cu-sulfate supplementation may redirect glucosinolates breakdown products, or produce secondary breakdown products by rearrangement reactions (Tripathi \& Mishra, 2007). Thus, dietary Cu supplementation can influence in a positive manner the nutritive value and potential toxic effects of the camelina meal. Pekel et al. (2009) noticed that $\mathrm{Cu}$ supplementation at the prophylactic level $(150 \mathrm{mg} /$ 
$\mathrm{kg}$ ) indicated an ability to improved live performance and carcass parameters of broilers fed the camelina diet. Youvalari et al. (2017) reported that treatments of canola meal, which is a member of the Brassica family with Cu-sulfate could alleviate adverse effects of glucosinolate on broilers performance.

Another method of alleviating the effects of the antinutritional factors, mentioned in literature, is the use of enzymes, like xylanase, amylase, protease, and phytase, in the corn-soybean diets for layers, which enhances layer performance (Cowieson \& Adeola, 2005) and which increases the apparent metabolisable energy (Meng et al., 2005) and the ileal digestibility of protein and amino acids (Zanella et al., 1999).

Limited information on amino acid digestibility from camelina meal and flaxseed meal for poultry are available. A few studies reported that camelina cake can be considered an energy source given its remaining oil content, but its digestibility coefficients for amino acid and crude protein are low indicating that it may contained high glucosinolate concentrations generally observed in camelina meal, thus limiting its utilization in swine diets (Kahindi et al., 2014; Graham et al., 2013).

The purpose of this study was to investigate in two in vivo digestibility trials on layers, the effects of $\Omega 3$ PUFA-enriched diet on the apparent faecal digestibility of the essential amino acids, as well as various feeding solutions to control the possible adverse effects that may occur in such situations.

\section{MATERIAL AND METHODS}

All animal experiments were conducted in compliance with the European Union Directive 2010/63/EU and in accordance with regulations set by the Ethical Commission of National Research and Development Institute for Biology and Animal Nutrition.

\section{Experimental design}

Experiment 1. The trial was conducted for 6 weeks on 72 Lohmann Brown layers (60 weeks), assigned to three groups (C1, E1-1, E2). Compared to the control diet (C1), the diet formulations for the experimental groups (E1-1 and E2) included 5\% flaxseed meal and $2 \%$ camelina meal (Table 1). Compared to $6 \mathrm{mg} \mathrm{Cu} / \mathrm{kg}$ feed from the premix of $\mathrm{C} 1$ and E1-1 diets, E2 diet had $150 \mathrm{mg} \mathrm{Cu} / \mathrm{kg}$ feed (from CuSO ${ }_{4} \cdot 5 \mathrm{H}_{2} \mathrm{O}$ ).

Experiment 2. The trial was conducted for 4 weeks on 96 Lohmann Brown layers (58 weeks) assigned to four groups (C2, E1-2, E3, E4). Compared to the control diet (C2), similar to $C 1$ from experiment 1, the diet formulations for the experimental groups (E1-2, E3 and E4) included 5\% flaxseed meal and 2\% camelina meal (Table 1). Compared to E1-2 diet (similar to E11), E3 and E4 diets contained $0.0125 \mathrm{~kg}$ cellulolytic enzyme/100 kg feed (Table 1). The enzyme was Biozim M6000 (Biomin, Austria), with $\beta$-xylanase $(6000 \mathrm{U} / \mathrm{g}$ ) as active substance, and $\beta$-glucanase as secondary substance. Compared to E3 diet, E4 diet had $150 \mathrm{mg}$ $\mathrm{Cu} / \mathrm{kg}$ feed, from CuSO $\mathrm{C}_{4} \cdot 5 \mathrm{H}_{2} \mathrm{O}$.

The hens used in both trials have been housed in experimental halls fitted with digestibility cages ( 2 layers per cage), which allow accurate weighing of the daily ingesta and excreta, with controlled environmental conditions (average temperature $23 \pm 1^{\circ} \mathrm{C}$; humidity $65 \pm 3 \%$; light regimen $6 \mathrm{~h} / 24 \mathrm{~h}$ ). Feed and water were supplied ad libitum. The productive parameters (feed conversion, laying percentage, average egg weight) were calculated from the daily records.

Balance period. The apparent faecal amino acids digestibility was evaluated using the methodology of Sirirat et al. (2013). The balance was conducted for 5 days, during week 3 . During this period, feed intake and average weights from each two cages (6 samples/group) of excreta voided (dry matter basis) were recorded and sampled for amino acid analysis. Amino acid retention ratio was calculated using the following equation:

Amino acid retention ratio $(\%)=\frac{(\mathrm{WFI} \times \mathrm{AAF})-(\mathrm{WEV} \times \mathrm{AAE})}{(\mathrm{WFI} \times \mathrm{AAF})} \times 100$

where: $\mathrm{WFI}=$ weight of feed intake; $\mathrm{AAF}=$ concentration of amino acid in feed; WEV = weight of total excreta voided; $\mathrm{AAE}=$ concentration of amino acid in total excreta.

\section{Chemical analysis}

Proximate composition. Standard methods were used to determine the concentration of crude protein (Kjeltec auto 1030 - Tecator Instruments, Hoganas, Sweden), crude fat (Soxtec 2055 - Foss Tecator, Sweden), crude fibre (Fibertec 2010 System - Foss Tecator, Sweden), crude ash (Caloris CL 1206 furnace, Romania) from feeds according to Regulation (EC) no. $152 / 2009$. The fatty acids were determined by the gas chromatography method (AOAC, 2000) using a PerkinElmer Clarus 500 GC (Massachusetts, United States), fitted with Flame lonization Detector (FID) and capillary separation column with high polar stationary phase TRACE TR-Fame, (Thermo Electron, Massachusetts, United States), size $60 \mathrm{~m} \times 0.25 \mathrm{~mm} \times 0.25 \mu \mathrm{m}$. 
Amino acids determination from samples of ingesta and droppings was performed by HPLC, using a method optimised and validated by Varzaru et al. (2013), and HPLC system Finnigan Surveyor Plus and HyperSil BDS C18 column, size $250 \times 4.6$ mm, $5 \mu \mathrm{m}$ (Thermo-Electron Corporation, Waltham, $\mathrm{MA})$.

\section{Statistical analysis}

The statistical analyses were performed using STATVIEW software for Windows (SAS, version 6.0). The data were subjected to one-way ANOVA followed by Fisher's test to detect the differences between the groups. Values of $p$ less than 0.05 were considered significantly different.

Table 1 - Formulations of the compound feeds used in the two trials.

\begin{tabular}{|c|c|c|c|c|c|c|c|}
\hline \multirow[t]{2}{*}{ Item } & \multicolumn{3}{|c|}{ Experiment 1} & \multicolumn{4}{|c|}{ Experiment 2} \\
\hline & C1 & E1-1 & E2 & $\mathrm{C} 2$ & E1-2 & E3 & E4 \\
\hline Corn, \% & 35.74 & 33.75 & 33.75 & 35.74 & 33.75 & 33.74 & 33.74 \\
\hline Rice, \% & 15.00 & 15.00 & 15.00 & 15.00 & 15.00 & 15.00 & 15.00 \\
\hline Wheat, \% & 10.00 & 10.00 & 10.00 & 10.00 & 10.00 & 10.00 & 10.00 \\
\hline Rapeseed meal, \% & 15.00 & 9.50 & 9.50 & 15.00 & 9.50 & 9.50 & 9.50 \\
\hline Soybean meal, \% & 9.00 & 9.00 & 9.00 & 9.00 & 9.00 & 9.00 & 9.00 \\
\hline Gluten, \% & 2.00 & 2.00 & 2.00 & 2.00 & 2.00 & 2.00 & 2.00 \\
\hline Flaxseed meal,\% & - & 5.00 & 5.00 & - & 5.00 & 5.00 & 5.00 \\
\hline Camelina meal, \% & - & 2.00 & 2.00 & - & 2.00 & 2.00 & 2.00 \\
\hline Oil, \% & 2.00 & 2.40 & 2.40 & 2.00 & 2.40 & 2.40 & 2.40 \\
\hline Monocalcium phosphate, \% & 1.06 & 1.06 & 1.06 & 1.06 & 1.06 & 1.06 & 1.06 \\
\hline Calcium carbonate, \% & 8.70 & 8.70 & 8.70 & 8.70 & 8.70 & 8.70 & 8.70 \\
\hline Salt, \% & 0.30 & 0.30 & 0.30 & 0.30 & 0.30 & 0.30 & 0.30 \\
\hline Methionine, \% & 0.15 & 0.12 & 0.12 & 0.15 & 0.12 & 0.12 & 0.12 \\
\hline Lysine, \% & - & 0.12 & 0.12 & 0.12 & 0.12 & 0.12 & 0.12 \\
\hline Choline, \% & 0.05 & 0.05 & 0.05 & 0.05 & 0.05 & 0.05 & 0.05 \\
\hline Enzyme, \% & - & - & - & - & - & 0.0125 & 0.0125 \\
\hline Vitamin-mineral premix, \% & $1.00 *$ & $1.00 *$ & $1.00 * *$ & $1.00 *$ & $1.00 *$ & $1.00^{*}$ & $1.00 * *$ \\
\hline Total & 100 & 100 & 100 & 100 & 100 & 100 & 100 \\
\hline
\end{tabular}

*1 kg premix contains: 1350000 IU/kg vit.A; 300000 IU/kg vit.D3; 2700 IU/kg vit.E; 200 mg/kg Vit.K; 200 mg/kg Vit.B1; 480 mg/kg Vit.B2; 1485 mg/kg pantothenic acid; 2700 mg/ $\mathrm{kg}$ nicotinic acid; $300 \mathrm{mg} / \mathrm{kg}$ vitamin B6; $4 \mathrm{mg} / \mathrm{kg}$ vitamin B7; $100 \mathrm{mg} / \mathrm{kg}$ vitamin B9; $1.8 \mathrm{mg} / \mathrm{kg}$ vitamin B12; $2500 \mathrm{mg} / \mathrm{kg}$ vitamin C; $7190 \mathrm{mg} / \mathrm{kg}$ manganese; $6000 \mathrm{mg} / \mathrm{kg}$ iron; 600 $\mathrm{mg} / \mathrm{kg}$ copper; $6000 \mathrm{mg} / \mathrm{kg}$ zinc; $50 \mathrm{mg} / \mathrm{kg}$ cobalt; $114 \mathrm{mg} / \mathrm{kg}$ iodine; $18 \mathrm{mg} / \mathrm{kg}$ selenium; ** The premix contains $15000 \mathrm{mg}$ Cu/kg compound feed.

\section{RESULTS}

\section{Feeding quality of the feeds}

The tested compound feeds formulations were isocaloric and isoprotein (Table 2). The small differences in the proximate chemical composition and in the amino acid's concentrations in the feeds from the two trials were due to the variation in the chemical composition of the raw materials used to manufacture the compound feeds, and also to the

Table 2 - Data on nutrients content of compound feeds used in the two trials

\begin{tabular}{|c|c|c|c|c|c|c|c|}
\hline \multirow[t]{2}{*}{ Item } & \multicolumn{3}{|c|}{ Experiment 1} & \multicolumn{4}{|c|}{ Experiment 2} \\
\hline & C1 & E1-1 & E2 & C2 & E1-2 & E3 & E4 \\
\hline $\mathrm{ME}, \mathrm{Kcal} / \mathrm{kg}$ & 2648.69 & 2665.43 & 2665.4 & 2540.8 & 2678.62 & 2678.62 & 2678.62 \\
\hline Protein, \% & 17.01 & 17.77 & 17.72 & 16.77 & 16.06 & 16.29 & 16.77 \\
\hline Fat, \% & 6.00 & 7.20 & 6.98 & 6.10 & 7.43 & 7.62 & 7.14 \\
\hline PUFA omega 3 & 1.96 & 8.51 & 8.28 & 1.82 & 8.55 & 8.14 & 8.17 \\
\hline Fibre, \% & 6.01 & 6.64 & 6.71 & 5.24 & 5.79 & 5.38 & 5.21 \\
\hline Ash, \% & 13.29 & 11.99 & 12.38 & 13.35 & 11.28 & 12.25 & 11.40 \\
\hline $\mathrm{Cu}, \mathrm{mg} / \mathrm{kg}$ & 6.28 & 6.70 & 156.33 & 11.11 & 11.72 & 15.84 & 161.05 \\
\hline \multicolumn{8}{|c|}{ Essential amino acids } \\
\hline Threonine, \% & 0.65 & 0.61 & 0.63 & 0.71 & 0.70 & 0.67 & 0.67 \\
\hline Valine, \% & 0.98 & 0.93 & 0.92 & 1.08 & 1.11 & 1.04 & 1.02 \\
\hline Phenylalanine, \% & 0.72 & 0.69 & 0.68 & 0.77 & 0.80 & 0.75 & 0.78 \\
\hline Isoleucine, \% & 0.61 & 0.57 & 0.55 & 0.68 & 0.71 & 0.66 & 0.70 \\
\hline Leucine, \% & 1.34 & 1.25 & 1.27 & 1.47 & 1.47 & 1.41 & 1.44 \\
\hline Lysine, \% & 0.76 & 0.80 & 0.77 & 0.76 & 0.73 & 0.73 & 0.79 \\
\hline Cystine, \% & 0.27 & 0.28 & 0.27 & 0.32 & 0.28 & 0.31 & 0.32 \\
\hline Methionine, \% & 0.45 & 0.42 & 0.43 & 0.38 & 0.36 & 0.37 & 0.37 \\
\hline
\end{tabular}


uncertainty degree of the analytical methods used for the respective determinations. The use of flaxseed and camelina meals in the formulations for the experimental groups from the two experiments, led to enriched diets in $\alpha$ linolenic acid (PUFA $\Omega 3$ acid), in average by 5.2 times compared to $C 1$ and $C 2$. In order to control the adverse effects of the antinutritional factors present in the two oleaginous meals, E2 and E4 diets, both enriched in PUFA $\Omega$ 3, have been supplemented with copper, compared to C1 and C2, respectively, as shown by their concentration of this trace element. Moreover, E4 diet was also supplemented with exogenous enzymes.

\section{Layer performance}

Experiment 1. The results obtained for feed conversion ratio (Table 3 ) were better $(p \leq 0.05)$ in the control group (C1) compared to the experimental groups enriched in PUFA $\Omega 3$, but the laying percentage and the average egg weight were not different $(p>0.05)$ between the groups.

Experiment 2. Table 3 data shows a better feed conversion ratio $(p \leq 0.05)$ in group E4 (enriched in PUFA $\Omega 3$, supplemented with $\mathrm{Cu}$ and enzyme mix), compared to E1-2 (enriched in PUFA $\Omega 3$ ), to E3 (enriched in PUFA $\Omega 3$ and enzyme mix) and to C2. The laying percentage was higher $(p>0.05)$ in E4 than in E1-2. The average egg weight didn't vary significantly in the groups (E3 and E4) compared to C2.

\section{Apparent faecal digestibility of the essential amino acids}

Experiment 1. In experiment 1 , the digestibility coefficients of the groups enriched in PUFA $\Omega 3$ (E1-

Table 3 - Layer performance (average values/group/ experiment).

\begin{tabular}{lccccc|cccccc}
\hline \multirow{2}{*}{ Item } & \multicolumn{4}{c}{ Experiment 1 } & \multicolumn{5}{c}{ Experiment 2 } \\
\cline { 2 - 11 } & C1 & E1-1 & E2 & SEM & P & C2 & E1-2 & E3 & E4 & SEM & $p$ \\
\hline $\begin{array}{l}\text { Feed conversion ratio } \\
\text { (kg CF/kg egg) }\end{array}$ & $1.84^{\mathrm{a}}$ & $1.96^{\mathrm{b}}$ & $2.02^{\mathrm{b}}$ & 0.02 & 0.01 & $1.93^{\mathrm{a}}$ & $2.01^{\mathrm{ab}}$ & $2.04^{\mathrm{b}}$ & $1.91^{\mathrm{c}}$ & 0.02 & 0.0382 \\
Laying percentage (\%) & $87.18^{\mathrm{a}}$ & $84.83^{\mathrm{a}}$ & $85.06^{\mathrm{a}}$ & 0.01 & 0.3775 & $88.66^{\mathrm{a}}$ & $86.19^{\mathrm{a}}$ & $87.32^{\mathrm{a}}$ & $90.73^{\mathrm{a}}$ & 0.51 & 0.4073 \\
Average egg weight (g) & $64.54^{\mathrm{a}}$ & $64.92^{\mathrm{a}}$ & $63.28^{\mathrm{a}}$ & 0.45 & 0.2793 & $65.07^{\mathrm{a}}$ & $64.76^{\mathrm{a}}$ & $64.94^{\mathrm{a}}$ & $65.02^{\mathrm{a}}$ & 0.16 & 0.9165 \\
\hline
\end{tabular}

In experiment 1: means in the same row with no common superscript are significantly different $(p<0.05)$. In experiment 2 : means in the same row with no common superscript are significantly different $(p<0.05)$.

SEM: standard error of the mean.

1 and E2), were lower $(p \leq 0.05)$ than in the control group (C1), for the studied essential amino acids (Table 4).

The results showed that in E1-1 diet (rich in PUFA $\Omega 3$ but with no supplemental $\mathrm{Cu}$ ), lysine digestibility decreased with $2.1 \%$, and methionine digestibility decreased with 3.3\% compared to C1. Also, cystine digestibility decreased with $2.1 \%$ in E1-1 and with $2.06 \%$ in E2, compared to $\mathrm{C} 1$. The higher level of $\mathrm{Cu}$ from E2 diet increased slightly lysine digestibility $(0.08 \%)$ and methionine digestibility (1.2\%) compared to group E1-1.

Table 4 - Apparent faecal essential amino acids digestibility (\%).

\begin{tabular}{|c|c|c|c|c|c|c|c|c|c|c|c|}
\hline \multirow{2}{*}{ Amino acid } & \multicolumn{5}{|c|}{ Experiment 1} & \multicolumn{6}{|c|}{ Experiment 2} \\
\hline & $\mathrm{C} 1$ & E1-1 & E2 & SEM & $p$ & $\mathrm{C2}$ & E1-2 & E3 & E4 & SEM & $p$ \\
\hline Threonine, \% & $80.46^{b}$ & $74.29^{a}$ & $74.44^{\mathrm{a}}$ & 0.91 & 0.0007 & $77.44^{\mathrm{a}}$ & $75.65^{a}$ & $76.11^{\mathrm{a}}$ & $77.15^{a}$ & 0.37 & 0.2785 \\
\hline Valine, \% & $84.30^{b}$ & $78.60^{a}$ & $79.97^{a}$ & 0.86 & 0.046 & $80.67^{a}$ & $79.54^{a}$ & $79.54^{a}$ & $81.73^{a}$ & 0.41 & 0.7585 \\
\hline Phenylalanine, \% & $88.39^{b}$ & $82.32^{a}$ & $78.77^{c}$ & 1.08 & $<0.0001$ & $85.52^{c}$ & $81.25^{a}$ & $84.83^{b}$ & $87.21^{d}$ & 0.55 & $<0.0001$ \\
\hline Isoleucine, \% & $83.20^{b}$ & $76.05^{a}$ & $77.34^{a}$ & 1.00 & 0.0018 & $80.21 \mathrm{ab}$ & $77.97^{a}$ & $80.45^{a b}$ & $81.73^{b}$ & 0.50 & 0.0384 \\
\hline Leucine, \% & $88.87^{b}$ & $84.74^{a}$ & $83.86^{a}$ & 0.69 & 0.0005 & 86.26 b & $84.21^{a}$ & 85.64 ab & 86.07 ab & 0.34 & 0.1287 \\
\hline Lysine, \% & $86.26^{b}$ & $84.41^{a}$ & $84.48^{a}$ & 0.37 & 0.0640 & $90.21^{b}$ & $88.25^{a}$ & $90.17^{b}$ & $90.48 b$ & 0.27 & 0.0017 \\
\hline Cystine, \% & 83.79 b & $81.14^{a b}$ & $80.90^{a}$ & 0.58 & 0.0796 & 83.64 b & $81.64^{a}$ & $84.02^{b}$ & $85.656^{c}$ & 0.39 & $<0.0001$ \\
\hline Methionine, \% & $89.83^{b}$ & $86.80^{a}$ & $87.91^{\text {a }}$ & 0.42 & 0.0022 & $86.16^{b}$ & $82.67^{\mathrm{a}}$ & $87.43^{b}$ & $90.24^{c}$ & 0.63 & $<0.0001$ \\
\hline
\end{tabular}

In experiment 1: means in the same row with no common superscript are significantly different $(p<0.05)$. In experiment 2 : means in the same row with no common superscript are significantly different $(p<0.05)$.

SEM: standard error of the mean.

Experiment 2. Similar to results of experiment 1 for group E1-1, the amino acids balance data (Table 4) showed a lower digestibility of the amino acids for group E1-2, compared to group C2. The enzyme inclusion in E1-2 diet, which thus became diet E3, increased significantly $(p \leq 0.05)$ the apparent digestibility coefficients for phenylalanine, lysine, cystine and methionine compared to E1-2. Table 4 
also shows that the simultaneous inclusion of copper and enzyme in the diet of group E4 increased ( $p \leq 0.05)$ lysine digestibility compared to group E1-2; increased $(p \leq 0.05)$ sulphur amino acids digestibility compared to groups C2, E1-2 and E3. Compared to group $\mathrm{C} 2$, which received a conventional feed, the highest increase of the digestibility coefficients was noticed in group E4, which were with $2.4 \%$ higher for cystine, with $4.7 \%$ for methionine and with $0.3 \%$ for lysine. Compared to E1-2 diet (enriched in PUFA $\Omega 3$ ), the use of the enzyme mix ( $\beta$-xylanase and $\beta$-glucanase) and of copper in E4 diet (enriched in PUFA $\Omega 3$ ), increased cystine digestibility with $4.9 \%$, methionine digestibility with $9.1 \%$ and lysine digestibility with $2.5 \%$.

\section{DISCUSSION}

Flaxseed and camelina are gaining popularity as feed ingredients because of their high content of PUFA $\Omega 3$, and their ability to increase PUFA $\Omega 3$ concentration in eggs when included in laying hens diets (Aziza et al., 2013). However, the content of antinutritional factors in camelina and flaxseed meal can decrease the digestibility of dietary proteins. In experiments conducted with broiler chickens, several authors reported significant decreases in digestibility of dry matter, nitrogen, and energy with increasing dietary camelina meal concentration (Acamovic et al., 1999; Thacker \& Widyaratne, 2012). Pekel et al. (2015) showed a poor energy and nitrogen utilization when camelina meal was added to broilers diet, due to a high viscosity observed in jejunal digesta caused by the glucosinolate content of camelina meal.

\section{Layer performance}

The level of $7 \%$ oleaginous meals used in the two experiments was moderate, compared to 10-15\% used in other studies (Cherian et al., 2009; Aziza et al., 2013), and had no significant effect ( $p>0.05)$ on laying percentage and egg weight. Different results were obtained by Aziza et al. (2013) when feeding 10 $\%$ flax or camelina meal. The authors observed higher egg production $(p<0.05)$ compared with a corn-soybased control diet. Cherian et al. (2009) showed that $15 \%$ dietary camelina meal had an adverse effect on the laying percentage and egg weight, compared to the control, while feeding $10 \%$ camelina meal only affected egg weight.

The copper supplementation of a diet which includes feeds from Brassica family has been proposed by other authors too (Tripathi \& Mishra, 2007; Pekel et al., 2009). On the other hand, Pekel \& Alp (2011), who used $250 \mathrm{mg} \mathrm{Cu} / \mathrm{kg}$ in layer diets with 10\% sunflower meal, concluded that increasing the dietary Cu intake did not affect layer performance. Balevi \& Coskun (2004) didn't notice significant effects of Cu supplements on egg production, average daily feed intake and feed conversion ratio. Jegede et al. (2015) showed that dietary supplements of 50 and $100 \mathrm{mg}$ $\mathrm{Cu} / \mathrm{kg}$ feed increased egg production compared to dietary supplements of $150 \mathrm{mg} \mathrm{Cu} / \mathrm{kg}$ feed.

The use of exogenous enzymes in cereal-based layer diets is beneficial because they can hydrolyse the nonstarch polysaccharides, reduce digesta viscosity and improve nutrient absorption and layer performance (Wang et al., 2005). Unlike other studies (Mirzaie et al., 2012), the average egg weight didn't vary significantly in the groups supplemented with enzyme (E3 and E4) compared to C2. The inclusion of xylanase by Mirzaie et al. (2012) increased egg production $(p<0.05)$, egg weight $(p<0.01)$ and feed conversion ratio $(p<0.01)$.

\section{Apparent faecal digestibility of the essential amino acids}

Varzaru et al. (2015) used 5\% flaxseed meal and $2 \%$ camelina meal in layer diets, and also noticed a decrease $(p \leq 0.05)$ of some amino acids (lysine, methionine, valine, arginine and alanine) versus a corn-soybean meal control. Aziza et al. (2013) conducted a trial on layers to evaluate, among others, crude protein digestibility when feeding a cornsoybean diet containing $10 \%$ camelina or flax meal and noticed a significant $(p<0.05)$ decrease of crude protein digestibility compared with the control diet. Literature has poor data on the effect of the dietary copper on amino acids digestibility. Thus, Rowan et al. (1991) unlike the findings of this study, noticed a better digestibility of some amino acids when $200 \mathrm{mg}$ $\mathrm{Cu} / \mathrm{kg}$ of feed were used in pig diets which included rapeseeds with less than $5 \mu \mathrm{mol} / \mathrm{kg}$ glucosinolates.

Glucosinolates and trypsin inhibitor are the major antinutritional factors in camelina co-products, in which total glucosinolate content ranged from 34.4 to $36.3 \mu \mathrm{mol} / \mathrm{g}$ and trypsin inhibitor activity from 12 to $28 \mathrm{TIU} / \mathrm{mg}$, according to Woyengo et al. (2017). In the same study, a content of 127 mg cyanogenic glucoside/ $\mathrm{kg}$ from flaxseed meal is reported, cyanogenic glucosides being the major antinutritional factors in flaxseed co-products. The mechanism by which dietary Cu supplementation could overcome the negative effects of glucosinolates can be explained in part by reducing their ileal concentration, by absorption from the intestinal lumen or conversion to other by-products (Tripathi \& Mishra, 2007). 
The results of experiment 2 are in agreement with the data reported by Mathlouthi et al. (2002), who noticed a significant increase of nutrient digestibility and of the apparent metabolisable energy, when xylanase and $\beta$-glucanase were used in rice-based broiler diets. Rutherfurd et al. (2007) also showed that the enzyme supplements to corn-soybean based diets, increased the ileal digestibility of amino acids in broilers, which was 2-3\% higher for methionine. Mushtaq et al. (2009) reported an improvement of the apparent metabolisable energy and digestibility coefficient of nitrogen when enzyme supplementation was used in diets with $30 \%$ cottonseed meal but failed to show any improvement in performance of birds fed on cottonseed meal-based diets.

The mechanisms whereby exogenous enzymes improve apparent amino acid digestibility coefficients are complex. Reducing gut viscosity and increasing cell wall permeability, xylanase facilitates the digestion of protein/amino acids (Selle et al., 2009). The recent finding of Moss et al. (2018) showed that enzyme supplementation of broilers diets containing canola meal, a plant from the same family as camelina, significantly increased the digestibility of 9 essential amino acids and 7 nonessential amino acids. Moreover, better responses were recorded in apparent ileal digestibilities of phosphorus, calcium, sodium, zinc and five other trace minerals. In spite of many studies which reported the effect of enzymes supplementation of diets on animal performance and nutrients digestibility, information is lacking on the effect of supplementing PUFA enriched diets with exogenous enzymes and copper, on amino acid digestibility.

In conclusion, supplementation of diets enriched in PUFA $\Omega 3$ with exogenous enzyme $(0.0125 \%)$ and $\mathrm{Cu}(150 \mathrm{mg} / \mathrm{kg})$, can alleviate the losses in apparent fecal digestibility of amino acids resulted from adding flaxseed meal and camelina meal in diets. Considering the lack of studies regarding the synergistic actions of copper and exogenous enzymes on amino acid digestibility from PUFA enriched diets, further researches are necessary.

\section{ACKNOWLEDGEMENTS}

This work was funded by the Romanian Ministry of Research and Innovation through Program 1 Developement National Research-Developement, Subprogram 1.2 - Institutional Performance - Projects funding excellence in $R \& D$, Contract no.17 PFE/ 17.10.2018, and project number 8PCCDI/2018 PC3, within PN-III-P1-1.2-PCCDI-2017.

\section{REFERENCES}

Acamovic T, Gilbert C, Lamb K, Walker KC. Nutritive value of Camelina sativa meal for poultry. British Poultry Science 1999;40(S1):27-27.

AOAC. Official method 996.01. Fat (total, saturated, unsaturated, and monounsaturated) in cereal products. 17 $7^{\text {th }}$ ed. Gaithersburg: Official Methods of Analysis of the AOAC; 2000.

Aziza AE, Panda AK, Quezada N, Cherian G. Nutrient digestibility, egg quality, and fatty acid composition of brown laying hens fed camelina or flaxseed meal. Journal of Applied Poultry Research 2013;22(4):832841 .

Balevi T, Coskun B. Effects of dietary copper on production and egg cholesterol content in laying hens. British Poultry Science 2004;45(4):530-534.

Cherian G, Campbell A, Parker T. Egg quality and lipid composition of eggs from hens fed Camelina sativa. Journal of Applied Poultry Research 2009;18(2):143-150.

Cherian G. Supplemental flax and impact on $n 3$ and $n 6$ polyunsaturated fatty acids in eggs. In: Hester PY, editor. Egg innovations and strategies for improvements. London: Academic Press; 2017. p.365-372.

Cowieson AJ, Adeola O. Carbohydrases, protease, and phytase have an additive beneficial effect in nutritionally marginal diets for broiler chicks. Poultry Science 2005;84(12):1860-1867.

Criste RD, Panaite TD, Ciurescu C, Ropota M, Rachieru D. Effects of moderate $(5 \%)$ levels of linseed in layer diets. Archiva Zootechnica $2009 ; 12(3): 11-21$

Graham AB, De Rouchey JM, Goodband RD, Tokach MD, Dritz SS, Thaler RC. Amino acid digestibility and energy concentration of fermented soybean meal and camelina meal for swine. Kansas Agricultural Experiment Station Research Reports 2013;10:246-255.

Jegede AV, Oso AO, Fafiolu AO, Sobayo RA, Idowu OM, Oduguwa OO. Effect of dietary copper on performance, serum and egg yolk cholesterol and copper residues in yolk of laying chickens. Slovak Journal of Animal Science 2015;48(1):29-36.

Kahindi RK, Woyengo TA, Thacker PA, Nyachoti CM. Energy and amino acid digestibility of camelina cake fed to growing pigs. Animal Feed Science and Technology 2014;193:93-101.

Liu WC, Kim IH. Effects of different dietary n-6: n-3 PUFA ratios on growth performance, blood lipid profiles, fatty acid composition of pork, carcass traits and meat quality in finishing pigs. Annals of Animal Science 2018;18(1):143-54.

Mathlouthi N, Lalles JP, Lepercq P, Juste C, Larbier M. Xylanase and $\beta$-glucanase supplementation improve conjugated bile acid fraction in intestinal contents and increase villus size of small intestine wall in broiler chickens fed a rye-based diet. Journal of Animal Science 2002;80(11):2773-2779.

Meng X, Slominski BA, Nyachoti CM, Campbell LD, Guenter W. Degradation of cell wall polysaccharides by combinations of carbohydrase enzymes and their effect on nutrient utilization and broiler chicken performance. Poultry Science 2005;84(1):37-47

Mirzaie S, Zaghari M, Aminzadeh S, Shivazad M, Mateos GG. Effects of wheat inclusion and xylanase supplementation of the diet on productive performance, nutrient retention, and endogenous intestinal enzyme activity of laying hens. Poultry Science 2012;91(2):413-425.

Moss AF, Chrystal PV, Dersjant-Li Y, Selle PH, Liu SY. Responses in digestibilities of macro-minerals, trace minerals and amino acids generated by exogenous phytase and xylanase in canola meal diets offered to broiler chickens. Animal Feed Science and Technology 2018;240:22-30. 
Varzaru I, Panaite TD, Cornescu GM, Olteanu M

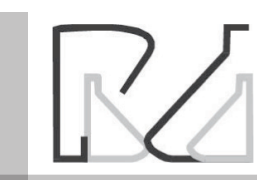

Apparent Faecal Digestibility of Essential Amino Acids from $\Omega 3$ Pufa Diets for Laying Hens
Mushtaq T, Sarwar M, Ahmad G, Mirza MA, Ahmad T, Athar M, et al. Influence of pre press solvent extracted cottonseed meal supplemented with exogenous enzyme and digestible lysine on performance, digestibility, carcass and immunity responses of broiler chickens. Journal of Animal Physiology and Animal Nutrition 2009;93(2):253-262.

Olteanu M, Criste RD, Panaite TD, Bunduc V, Panaite CV, Ropota M, et al. Study on the efficiency of grape seed meals used as antioxidants in layer diets enriched with polyunsaturated fatty acids compared with vitamin E. Brazilian Journal of Poultry Science 2016;18(4):655-62.

Pekel AY, Alp M. Effects of different dietary copper sources on laying hen performance and egg yolk cholesterol. Journal of Applied Poultry Research 2011;20(4):506-513.

Pekel AY, Kim JI, Chapple C, Adeola O. Nutritional characteristics of camelina meal for 3-week-old broiler chickens. Poultry Science 2015;94(3):371378.

Pekel AY, Patterson PH, Hulet RM, Acar N, Cravener TL, Dowler DB, et al. Dietary camelina meal versus flaxseed with and without supplemental copper for broiler chickens: Live performance and processing yield. Poultry Science 2009;88(11):2392-2398.

Regulations (EC) no 152/2009 laying down the methods of sampling and analysis for the official control of feed. Official Journal of the European Union L54; 2009

Rowan TG, Lawrence TL, Kershaw SJ. Effects of dietary copper and a probiotic on glucosinolate concentrations in ileal digesta and in faeces of growing pigs given diets based on rapeseed meals. Animal Feed Science and Technology 1991;35(3-4):247-258.

Rutherfurd SM, Chung TK, Moughan PJ. The effect of a commercial enzyme preparation on apparent metabolizable energy, the true ileal amino acid digestibility, and endogenous ileal lysine losses in broiler chickens. Poultry Science 2007;86(4):665-672

Selle PH, Ravindran V, Partridge GG. Beneficial effects of xylanase and/or phytase inclusions on ileal amino acid digestibility, energy utilisation, mineral retention and growth performance in wheat-based broiler diets. Animal Feed Science and Technology 2009;153(3-4):303-313.

Shahidi F, Ambigaipalan P. Omega-3 polyunsaturated fatty acids and their health benefits. Annual Review of Food Science and Technology 2018;9:345-381
Sirirat N, Lu JJ, Hung ATY, Lien TF. Effect of different levels of nanoparticles chromium picolinate supplementation on performance, egg quality, mineral retention, and tissues minerals accumulation in layer chickens. Journal of Agricultural Science 2013;5:150-159.

Thacker P, Widyaratne G. Effects of expeller pressed camelina meal and/or canola meal on digestibility, performance and fatty acid composition of broiler chickens fed wheat-soybean meal-based diets. Archives of Animal Nutrition 2012;66:402-415.

Tripathi MK, Mishra AS. Glucosinolates in animal nutrition: A review. Animal Feed Science and Technology 2007;132:1-27.

Varzaru I, Panaite T, Untea A, Cornescu G, Ropota M, Van I. Amino acid apparent digestibility assessment from laying hens diets supplemented with oil industry byproducts. Lucrări Științifice-Universitatea de Științe Agricole și Medicină Veterinară, Seria Zootehnie 2015;63:18-23.

Varzaru I, Untea AE, Martura T, Olteanu M, Panaite TD, Schitea M, Van I. Development and validation of an RP-HPLC method for methionine, cystine and lysine separation and determination in corn samples. Revista de Chimie Bucharest 2013;64:673-679.

Wang ZR, Qiao SY, Lu WQ, Li DF. Effects of enzyme supplementation on performance, nutrient digestibility, gastrointestinal morphology, and volatile fatty acid profiles in the hindgut of broilers fed wheat-based diet. Poultry Science 2005;84:875-881.

Woyengo TA, Beltranena E, Zijlstra RT. Effect of anti-nutritional factors of oilseed co-products on feed intake of pigs and poultry. Animal Feed Science and Technology 2017;233:76-86.

Youvalari SA, Farhoomand P, Kanani PB, Ghasemabad BH. Effects of copper sulfate and arginine supplements on performance and carcass traits in broiler chickens fed with canola meal based diet. Iranian Journal of Applied Animal Science 2017:7:647-654.

Zanella I, Sakomura NK, Silversides FG, Fiqueirdo A. Effect of enzyme supplementation of broiler diets based on corn and soybeans. Poultry Science 1999;78:561-568.

Zotte AD, Andrighetto I, Giaccone V, Marchesini G. Dietary enrichment of n-3 PUFA for laying hens: effect of different sources on production, composition and quality of eggs. Animal Science Papers and Reports 2015;33:411-424 
